\title{
A JURY'S PRE-TRIAL KNOWLEDGE IN HISTORICAL PERSPECTIVE: THE DISTINCTION BETWEEN PRE-TRIAL INFORMATION AND "PREJUDICIAL" PUBLICITY
}

\author{
JOSEPH M. HASSETT*
}

It seems odd, in retrospect, that the fate of those accused of sophisticated crimes such as the Watergate cover-up should be placed in the hands of a jury composed of people whose familiarity with public issues was on a par with two potential jurors at G. Gordon Liddy's trial who had never heard of the Watergate break-in. ${ }^{1}$ Yet that was exactly what seemed to be required by the fair trial partisans of the so-called "free press versus fair trial" controversy over the effect of pre-trial publicity on the fairness of a trial. The unique events preceding the trial of H.R. Haldeman, John Ehrlichman, John Mitchell, Robert Mardian and Kenneth Parkinson in the Watergate case crystallized the issues of this controversy in a way that calls for re-examination of the underlying principles.

The free press versus fair trial dispute seems to be an unlikely conflict. Both lawyers and journalists would no doubt maintain that they were trying to get at the "truth" behind Watergate. But, at least since the time that Pilate, the Roman governor of Judea, wondered aloud "Quid est veritas?" there has been no easy answer to the question. Newspaper and television reporters think they are advancing the cause of truth when they make revelations about people accused or suspected of crime. Although fairness can be more important than truth, one would hope that the trials of accused criminals would also aim at getting to the truth of the matter.

Nonetheless, one faction in the dispute, spurred by mid-sixties events such as the reversal of the murder conviction of Dr. Sam Sheppard on grounds of press interference with a fair trial, ${ }^{2}$ has increasingly taken the position that the publicity generated in the reporter's search for "truth" was tainting the minds of potential jurors and interfering with the Sixth Amendment right to

\footnotetext{
* Partner, Hogan \& Hartson, Washington, D.C.

1. United States v. Liddy, 509 F.2d 428, 437 n.15 (D.C. Cir. 1974), cert. denied, 420 U.S. 911 (1975).

2. Sheppard v. Maxwell, 384 U.S. 333 (1966), rev'g 346 F.2d 707 (1965). Sheppard, an Ohio doctor, had originally been convicted of the murder of his wife in a highly publicized 1954 trial in the Court of Common Pleas of Cuyahoga County, Ohio. The conviction was upheld on appeal. State v. Sheppard, 100 Ohio App. 345, 128 N.E.2d 471 (1955), aff'd, 165 Ohio St. 293, 135 N.E.2d 340, cert. denied, 352 U.S. 910 (1956).
} 
trial by an impartial jury. This viewpoint probably reached its zenith in June 1973, when columnist Joseph Alsop predicted that the information disclosed in public hearings by the Senate Watergate Committee would make it impossible to find twelve impartial jurors to decide any subsequent criminal case. ${ }^{3}$ Thus, Alsop did for the mind what the Supreme Court would do for the eye by suggesting in Nebraska Press Ass'n. $v$. Stuart ${ }^{4}$ that Jack Ruby could not have had a fair trial anywhere in the United States. That suggestion seemed to say that people who had seen Ruby shoot Lee Harvey Oswald on television could not give Ruby a fair trial. If so, a fair jury seems inclined to avert its eyes from the facts. Likewise, if a well informed student of public affairs is, for that very reason, disqualified from sitting on a jury in matters of public moment, then there is a fundamental flaw in the promise of a fair trial by citizens. Herbert Spencer's suggestion that a jury is representative of average stupidity ${ }^{5}$ seems too true.

The idea that ignorance of public affairs is an attribute of a good juror was dealt a heavy blow by the U.S. Court of Appeals decision affirming the convictions of President Nixon's principal lieutenants in the Watergate cover-up. ${ }^{6}$ However, the Court's continuing concern that it should monitor the jury's sources of knowledge about the case kept the door open to a dangerous judicial review of the fairness of journalistic stories and comment.

The unfolding of Watergate took place in an atmosphere in which the belief in the need for empty-headed jurors was more than the usual Alsopian doom and gloom. Special Prosecutor Cox had formally called upon the Senate Watergate Committee to suspend public hearings lest pre-trial publicity interfere with fair trials. ${ }^{7}$ When this request was denied, ${ }^{8}$ the Special Prosecutor went to court. He asked Judge Sirica to condition the immunity the Committee was seeking for the testimony of John Dean and Jeb Magruder on a requirement that the testimony be taken in Executive Session. ${ }^{9}$

The Special Prosecutor's concern was far from fanciful. He relied on a number of cases including Sheppard $v$. Maxwell, ${ }^{10}$ the celebrated case of Dr. Sam Sheppard. In Sheppard, the Supreme Court analyzed the effect of newspaper publicity on a fair trial in terms of what it called the "undeviating rule of this Court" expressed over half a century ago in Patterson v. Colorado, ${ }^{1}$ that

\footnotetext{
3. Washington Post, June 4, 1973, $\$$ A, at 23, col. 1 .

4. 427 U.S. 539,549 n.3 (1976).

5. H. Spencer, Representative Government, in Essays: Moral, Political and Aesthetic 182 (1868).

6. United States v. Haldeman, 559 F.2d 31 (D.C. Cir. 1976), cert. denied, 431 U.S. 933 (1977).

7. Watergate Special Prosecution force, Report, at 208 (1975).

8. Id.

9. Application of U.S. Senate Select Comm. on Pres. Campaign Activities, 361 F. Supp. 1270 (D.D.C. 1973).

10. See note 2 , supra.

11. 205 U.S. 454 (1907).
} 
" $[\mathrm{t}]$ he theory of our system is that the conclusions to be reached in a case will be induced only by evidence and argument in open court, and not by any outside influence, whether of private talk or public print."12 In fact, the quotation from Justice Oliver Wendell Holmes' opinion in Patterson v. Colorado was no more than a justification for failing to overturn the action of the Colorado court in imposing contempt penalties on Patterson for his audacity in criticizing that court with not only the written word, but a cartoon as well. The quotation had nothing to do with the effect of knowledge on a potential juror's ability to be fair. ${ }^{13} \mathrm{By}$ answering questions pertaining to the fairness of a trial in terms of a jury free from "outside" influences, the court was, however subtly, moving in the direction of saying that the mind of a good juror should be a blank slate. It is only a short step from the rationale of the Sheppard case to the conclusion that a good citizen cannot be a fair and impartial juror in a matter of public moment.

Good citizens had been exposed to, and, no doubt, influenced by, a mass of information about Watergate. It was one of the most widely publicized events in history. A poll commissioned by the defendants in the cover-up case suggested that 93 percent of the Washington population knew of the indictments in the case. ${ }^{14}$ Moreover, as pointed out by Judge MacKinnon, the lone dissenting voice from the decision of the Court en banc, "every one of the actual jurors had been exposed to the pre-trial publicity; most had witnessed the Senate hearings on television ...." [emphasis in original]. ${ }^{15}$ If a potential juror's relevant knowledge obtained from sources other than "evidence and argument in open court" disqualified the juror as partial, then Judge MacKinnon was right in believing that Haldeman, Ehrlichman and Mitchell did not get a fair trial.

In fact, the origin and history of the jury are at odds with the idea that a juror should not have extrajudicial knowledge about the events at issue in a trial. The hallmark of the early jury was that its members would be of the vicimage with knowledge of the events at issue. The contrast between the notion that the mind of the juror should be a blank slate and the origins of the jury is reflected by the 1280 decision of the judges that, when an issue arose about an act in Florence, Florentine merchants living in London should be summoned to serve as jurors. ${ }^{16}$

The idea that the jury should be drawn from those most likely to know the

12. Id. at 462, quoted in Sheppard v. Maxwell, 384 U.S. at 351.

13. Rather, the issue at hand was the constitutional right of a writer or cartoonist to comment upon and provide his personal evaluation of the performance of the Supreme Court of Colorado.

14. 559 F.2d at 144 . The survey used as its sample population those respondents who were eligible to vote and therefore eligible to serve on a jury in the city.

15. Id. at 155 (MacKinnon, J., concurring and dissenting).

16. See J. Thayer, A Preliminary Treatise on Evidence at the Common Law 94 (1898) [hereinafter cited as THAYER]. 
facts is also reflected in the 1374 statement of Chief Justice Belknap that the court should not proceed to determine who owns a parcel of land if, among the potential jurors it "does not see six, or at least five, men of the hundred where the tenements are, to inform the others who are further away." 17 " $A$ multo fortiori," said Belknap, "those of one county cannot try a thing which is in another county." ${ }^{8}$ A similar illustration of the jury's power to act on its own knowledge is found in the pronouncement of Justice Vavasour in 1499 that, although no evidence is given on either side, "yet the jury shall give their verdict for one side or the other." 19

There is no clearer indication of the early jury's right to rely on its own knowledge than the principle underlying the writ of attaint that an erroneous verdict was false as well. The writ of attaint was the early method of reviewing a jury verdict, which was brought before a jury of twenty-four new jurors who not only reconsidered the prior verdict, but also tried the original jurors for perjury. The punishment fixed for attainted jurors suggests the solemnity of their duties. As recounted by Sir John Fortescue in his 1470 panegyric to English law, De Laudibus Legae Angliae, the punishment was no slap on the wrist:

All of the first jury shall be committed to the King's prison, their goods shall be confiscated, their possessions seized into the King's hands, their habitations and houses shall be pulled down, their woodland shall be felled, their meadows shall be plowed up and they themselves forever thenceforward be esteemed in the eye of the law infamous. ${ }^{20}$

This penalty reinforced the juror's duty to be both knowledgeable and fair. That the early law saw no inconsistency between an informed jury and a fair one is further illustrated by Fortescue's boast that the jurors, who are chosen from "the neighborhood where the matter in question is supposed to exist or take place," and thus are informed, are yet "indifferent between the parties, subject to challenge by both. ..."21

Juror "indifference" as the standard of fairness is recognized today as the governing measure of the Sixth Amendment guarantee of an "impartial" jury. Impartiality is usually construed in terms of Sir Edward Coke's pronouncement that a juror ought "to be indifferent as he stands unsworne." 22 That Coke did not mean "ignorant" when he said "indifferent" is apparent from his further observation that "trial shall be had in the town, parish, or hamlet ... within which the matter of fact issuable is alleged, which is most certain

17. See id. at 91, quoting Y.B. 48 Edw. III 30, 17; Lib. Ass. 48, 5.

18. Id.

19. Id. at 133, quoting Y.B. H. VII. 29, 4.

20. Fortescue, De Laudibus Legum Angliae, xxvi (c. 1468), quoted in T. Plucknett, A ConCise History of the Common LAW 125 (4th ed. 1948).

21. Thayer, supra note 16, at 131, discussing Fortescue's De Laudibus Legum Angliae.

22. E. Coke, Commentary Upon LitTleton $\$ 155$ b (19th ed. London 1832). 
and nearest thereto, the Inhabitants whereof may have the better and more certain knowledge of the fact." [emphasis added] ${ }^{23}$

This ancient right of the jury to rely on its own knowledge of the facts is the source of the jury's great virtue of independence. The jury's knowledge of facts unknown to the king's judges is a basis for independent action to protect popular conceptions of fairness against encroachment by the central government. The view that the jury's knowledge taints its fairness may be overlooking the fact that, historically, the inscrutable "voice of the countryside"24 heard in the jury's verdict was the voice of the people speaking independently of government.

The relationship between the independence of the jury and its right to rely on its own knowledge is illustrated by the classic decision in Bushell's Case $^{25}$ in 1670. Bushell and his codefendants had been jurors at the trial of the Quakers William Penn and William Mead for taking part in an unlawful assembly. The court refused to accept the jury's verdict that Penn was "[g]uilty of speaking in Gracechurch Street"26 and demanded a verdict of guilty or not guilty of the charge of unlawful assembly. The seriousness of the court's threat that "we will have a verdict, by the help of God, or you shall starve for it" 27 is manifest from the report that

The court swore several persons, [sic] to keep the Jury all night without meat, drink, fire, or any other accommodation; they had not so much as a chamberpot, though desired. ${ }^{28}$

When, at last, Bushell and his fellow jurors returned a verdict of "not guilty" they were fined and imprisoned for giving a verdict against the evidence and against the direction of the court. They were released on habeas corpus by Chief Justice Vaughan, whose memorable opinion ended the punishment of jurors for their verdicts. ${ }^{29}$ Vaughan's opinion is a potent blend of bold policy and ancient learning. The opinion both confirms the role of jurors as finders of the facts testified to by witnesses, while simultaneously using the right of the jurors to rely on their own personal knowledge as a justification for their independence. As to the impropriety of punishing the jury for returning a verdict against the evidence, Vaughan distinguishes between a witness and a juror:

[A] witness swears but to what he hath heard or seen, generally or more largely, to what hath fallen under his senses. But a jury-man swears to what

23. Id. at 125 .

24. 2 F. Pollock \& F. Maitland, The History of the English law 624 (2d. ed. 1898).

25. Vaughan 135, 125 Eng. Rep. 1006 (C.P. 1670).

26. 6 T. Howell, A Complete Collection of State Trials 962 (London 1816).

27. Id. at 963 .

28. $I d$. at 964 .

29. Note 25, supra. 
he can infer and conclude from the testimony of such witnesses, by the act and force of his understanding, to be the fact inquired after . . . ${ }^{30}$

Thus, for Vaughan, an erroneous verdict is not false, and is no basis for punishment. Even so, when Vaughan addresses the charge that the jury acted against the direction of the court, he remembers that the jury has a right to rest upon its own knowledge. That right establishes its independence of the court. The jury can hardly be required to accept the judge's view of the facts, says Vaughan, because the judge knows only what he has heard from the evidence given in court, whereas the jury may know matters of their own private knowledge of which the judge knows nothing. ${ }^{31}$ They have the power to discredit all that is given in evidence in court and even to decide the case though no evidence at all were given in court on either side. Vaughan concludes that it is "absurd" to fine a jury for finding against the evidence, when the judge knows but part of it; for "the better and greater part of the evidence may be wholly unknown to him. ...."32

Vaughan would have been startled to read of the "undeviating rule" referred to in Sheppard $v$. Maxwell that the jury's verdict must be based only on "evidence and argument in open court." ${ }^{33}$ Nor would Vaughan be at home with the view that the well informed citizen should be disqualified from serving on a Watergate-related jury.

A significant turning point on the long road from Bushell's Case to Watergate is found in another widely publicized, political cause célèbre from an earlier era, the 1807 treason trial of Aaron Burr. ${ }^{34}$ Chief Justice Marshall's rulings on the qualifications of jurors at Burr's trial drew a distinction between a juror's personal knowledge and knowledge obtained from newspapers ${ }^{35}$ thereby casting what may have been the first stone in the free press versus fair trial controversy.

Burr's trial was set against a background of bitter strife between Jeffersonian Republicans and the waning Federalists. This hot debate in the new republic gave birth to a partisan press. Public debate as to the role of the press was brought into sharp focus by the success of the Federalists in enacting the Alien and Sedition Acts in 1798. The trial of Burr came on the heels of the impeachment of the feisty Federalist Judge, Samuel Chase, on charges that included the impropriety of his rulings with respect to the selection of a jury at the trial of James Callender ${ }^{36}$ in 1800 for violation of the Sedition Act. The atmosphere at Callender's trial is background to Burr's. The indictment

30. Vaughan 142, 125 Eng. Rep. at 1009.

31. Id. at 147,125 Eng. Rep. at 1012 .

32. Id. at 149, 125 Eng. Rep. at 1013 .

33. See text accompanying notes 11 and 12 , supra

34. United States v. Burr, 25 F. Cas. 55 (C.C.D. Va. 1807) (No. 14,693).

35. United States v. Burr, 25 F. Cas. 49 (C.C.D. Va. 1807) (No. 14,692g).

36. United States v. Callender, 25 F. Cas. 239 (C.C.D. Va. 1800) (No. 14,709). 
against Callender charged that he had seditiously libeled President Adams through publication of The Prospect Before $U s$ in which he stated, among other things, that President Adams "was a professed aristocrat"37 and that, "In the two first [sic] years of his presidency, he has contrived pretenses to double the annual expense of government by useless fleets, armies, sinecures and jobs of every possible description." 38

The official compiler of the earlier federal cases gives this vivid picture of the passions which surrounded the trial:

The tempest which this trial excited can now hardly be understood. The papers, for the first time in our history, were crammed with detailed reports, in which evidence and speeches were given at large. Virginia was in a flame; for even before the trial, affidavits were circulated in which it was stated that upon starting for Richmond, Judge Chase had publicly announced that "he would teach the lawyers in Virginia the difference between the liberty and the licentiousness of the press" (see Chase's Trial, 43); and that he had told the marshal "not to put any of those creatures called Democrats on the jury" 39 (Id. 44).

It seems clear that potential jurors were not ignorant of the case. On voir dire examination of potential jurors, Judge Chase allowed only one question: "Have you ever formed and delivered an opinion upon the charges contained in the indictment?" ${ }^{40}$ Chase explained that the juror must have delivered an opinion, as well as formed it, since "the whole country have heard the case, and very probably, formed an opinion." 41

Callender was convicted by the jury and, shortly thereafter, Chase was impeached by the House, but acquitted by the Senate. Riding the circuit two years later, Chief Justice Marshall set out to preside at the trial of Aaron Burr. As with the Callender case, the forthcoming trial was the subject of considerable attention in the press. Luther Martin, counsel for Burr, noted "the inflammatory articles which had been published against Colonel Burr in the Alexandria Expositor and other newspapers . .".42 Martin left little doubt about his view of the reliability of those articles when he observed: "that it was a libel upon Virginia, a blot upon the whole state, to assert, that twelve men could not be found to decide such a case, with no other knowledge that [sic] what they had picked up from newspapers." 43

Marshall's opinion deals with the selection of a jury in the heated circumstances of Burr's trial. He begins by laying down the general principle that

\footnotetext{
37. Id. at 239 .

38. Id. at $239-40$.

39. Id. at 258 , Note 1 .

40. Id. at 244 .

41. Id.

42. 25 F. Cas. at 49.

43. Id. at 77 .
} 
the impartiality of a juror is destroyed, not by mere knowledge of the case, or even by an opinion or predisposition, but only by "those strong and deep impressions which will close the mind against the testimony that may be offered in opposition to them, which will combat that testimony and resist its force ...."44

It is significant that Marshall is not talking about knowledge of the facts but about a predisposition against consideration of the facts. One might wonder what distinguishes the situation where knowledge of the facts is a liberating influence on the mind from the case where knowledge is but fodder for confining prejudice. William Hawkins, the great eighteenth century codifier, summed up the prevailing viewpoint on this tricky question in favor of the liberating powers of knowledge. Hawkins concluded that it "shall be a good challenge of a juror in respect of his indifferency"

that he has declared his opinion beforehand that the party is guilty, or will be hanged or the like. Yet it hath been adjudged, that if it shall appear that the juror made such declaration from his knowledge of the cause, and not out of any ill will to the party, it is no cause of challenge. [emphasis added] ${ }^{45}$

Marshall considers this resolution in terms of the distinction between knowledge and personal animus, but finds it unnecessary to accept or reject it:

Without determining whether the case put by Hawk. bk. 2, c. $43, \S 28$, be law or not, it is sufficient to observe that this case is totally different. The opinion which is there declared to constitute no cause of challenge is one formed by the juror on his own knowledge; in this case the opinion is formed on report and newspaper publications. ${ }^{46}$

Yet, in an interesting adumbration of the very issues that would be presented by Watergate, Marshall hesitates to rule that a well informed citizen makes a bad juror:

It would seem to the court that to say that any man who had formed an opinion on any fact conducive to the final decision of the case would therefore be considered as disqualified from serving on the jury, would exclude intelligent and observing men, whose minds were really in a situation to decide upon the whole case according to the testimony, and would perhaps be applying the letter of the rule requiring an impartial jury with a strictness which is not necessary for the preservation of the rule itself. ${ }^{47}$

The solution, said Marshall, was to "hear the statement"48 made by the potential juror and determine from what the juror had said "the strength and nature of the opinion which has been formed." 49 Thus Marshall adhered to the

44. Id. at 51 .

45. 2 W. Hawkins, A Treatise of the Pleas of the Crown 578 (ch. 43, \& 28) (8th ed. London 1824).

46. 25 F. Cas. at 52 .

47. Id. at 51 .

48. Id.

49. Id. 
same general question used by Judge Chase, i.e., whether the potential juror had "made up and delivered" an opinion on the case or-and only here did he differ from Chase-an essential element of it. The focus of inquiry for Marshall was not the nature or quality of the particular newspaper reports, but the relative openness of the particular juror's mind as objectively manifested in any statements he may have made. Finally, it is of interest that Marshall is unwilling to rule that an opinion based on personal knowledge is objectionable.

Even though the jury's primary role as trier of facts is well established, the ancient right of the jury to rely on its own knowledge is not easily extinguished. Indeed, as late as 1834 , a South Carolina court held that the jury may act "in some degree from their own knowledge of the character of the parties and their witnesses; it is for this reason that the jurors are drawn from the vicinage." ${ }^{50}$ It is still true today that a juror may also be a witness, although it is required that the juror be sworn as a witness and state his extrajudicial knowledge on the record. ${ }^{51}$ However, this requirement developed for reasons entirely independent of any suggestion that a juror's knowledge would taint his ability to be impartial; rather it developed from the need for a new method of reviewing an erroneous verdict to replace the device of punishment. Punishment had been argued out of existence by the sheer force of Vaughan's conclusive opinion in Bushell's Case. The traditional device of granting a new trial in cases where jurors had violated some formalistic duty, such as eating prior to reaching a verdict, was adapted for use in cases of violations of their judicial duty such as failure to find the facts accurately. ${ }^{52} \mathrm{But}$ a new trial for a verdict against the evidence is out of harmony with the right of the jury to rely on its private knowledge of the facts in reaching a verdict. Thus, by the middle of the seventeenth century, we find it said that "If a jury give a verdict of their own knowledge they ought to tell the court so that they may be sworn as witnesses . . . the fair way is to tell the court before they are sworn that they have evidence to give[.]"53 Although such procedure at this stage seems more an exhortation than a rule, by 1816 it seems to have been assumed that a new trial might have been granted if a judge had directed a jury to find a verdict of their own knowledge. ${ }^{54}$

Wigmore observes that the "comparative recency" in acceptance of the requirement that a juror state his or her personal knowledge on the record "accounts perhaps for the frequent statutory declaration of the principle in the

50. McKain v. Love, 13 S.C.L. 188, 189, 2 Hill 505, 506 (1834).

51. $6 \mathrm{~J}$. Wigmore, Evidence $\$ 1800$ (Chadbourn rev. 1976).

52. PlucknetT, supra note 20, at 128-29.

53. Anonymous, 91 Eng. Rep. 352, 1 Salk. 405 (1702), quoted in W. Holdsworth, A History of ENGLish LAw 336 (3d ed. 1922).

54. Holdsworth, supra note 53, at 336. 
legislation of the 1800 s in this country." 55 The fact that this principle needed to be declared by statute in the $1800 \mathrm{~s}$ is a further indication of the traditional understanding that the Sixth Amendment guarantee of an impartial jury did not require an ignorant one.

Today the principle is almost a necessary consequence of the hearsay rule. The theory that each party's evidence should be vigorously tested by the opponent's cross-examination is a further reason why a juror should state extrajudicial knowledge on the record. The important point is that the historical impetus for the requirement stems not from any thought that knowledge would render a juror partial, but from a desire to provide a mode of reviewing erroneous verdicts.

Justice Stewart overlooked this point in his recent opinion for the Court in Gannett Co., Inc. v. DePasquale ${ }^{56}$ He cites Blackstone's observation that if a juror knows of a matter at issue, he "may give his evidence publicly in court" 57 as an indication that the common law rule that jurors could give evidence against a defendant was "explictly rejected by the Sixth Amendment provision that defendant is entitled to be tried by an impartial jury." "58 In fact, the passage in Blackstone cited by Stewart points out that the practice of requiring that a juror give his evidence publicly in court was introduced "together with new trials" because the practice of a jury's reliance upon its private knowledge was "quite imcompatible" with the grant of a motion for a new trial on the ground that the verdict was contrary to the evidence. ${ }^{59}$ Blackstone does not suggest that an informed jury could not be impartial.

Until the 1960s, the selection of an impartial jury continued to be governed by the principles articulated by Marshall in the early years of the republic. There were refinements, such as the clarification in an 1878 decision reviewing a bigamy conviction from the territory of Utah, ${ }^{60}$ that a juror's declaration of an opinion was only one form of showing its strength and that a strong opinion, even if not expressed, could be disqualifying. But there was no major departure from the basic principles until the 1963 case of Rideau v. Louisiana. ${ }^{\mathbf{6}}$

Wilbert Rideau was arrested a few hours after a bank robber in Lake Charles, Louisiana killed a bank employee and kidnapped three others. On the night of his arrest, Rideau made detailed oral and written confessions to these crimes. The following morning a sound film was made of an interview

55. WIGMORE, supra note 51.

56. 47 U.S.L.W. 4902, 4906 (July 2, 1979).

57. 3 W. Blackstone, Commentaries 375 , cited in Gannett Co. v. DePasquale, 47 U.S.L.W. at 4906 n. 13 .

58. 47 U.S.L.W. at $4906-07$.

59. Blackstone, supra note 57 , at $374-75$.

60. Reynolds v. United States, 98 U.S. 145, 157 (1878)

61. 373 U.S. 723 (1963). 
between Rideau and the sheriff in which Rideau admitted the crimes again. Later that day and on the two succeeding days the film was broadcast over a television station in Lake Charles. The station program director later testified that he believed, on the basis of rating information, that 24,000 people were watching at the time of the first showing, 53,000 the second time, and 29,000 the third. The amount of overlap was unclear. Calcasieau Parish, in which Lake Charles is located, had a population of approximately 150,000 people.

Rideau was tried and convicted of murder two months after his arrest and confession. His conviction was affirmed by the Louisiana Supreme Court. ${ }^{62}$ The U.S. Supreme Court reversed the conviction on the ground that the trial court's failure to grant a motion for change of venue deprived Rideau of due process of law. ${ }^{63}$

It appears from the dissenting opinion that nine of the jurors at Rideau's trial had not seen the televised "interview," and that the three who had seen it testified that they could lay aside any opinion they might have formed with respect to Rideau. ${ }^{64}$ Neither opinion discusses what, if any, opinions concerning Rideau were held or expressed by any of the jurors, or the source or strength of any such opinions.

Justice Stewart's majority opinion did not analyze the effect that any knowledge of the confession might have had on the ability of the jury to be impartial. Indeed, Stewart's opinion seemed to make a virtue of the fact that the Court reached its conclusions "without pausing to examine a particularized transcript of the [voir dire] examination of the members of the jury." 65 Instead of inquiring into the acutal effect of the particular information or "publicity" (the televised confession) on the members of the jury, the Court looked to the nature of the publicity, and then made assumptions as to its likely effect on the community as a whole.

As to the nature of the publicity, the Court pronounced with Delphic grandeur that: "For anyone who has ever watched television the conclusion cannot be avoided that this spectacle, to the tens and thousands of people who saw and heard it, in a very real sense was Rideau's trial-at which he pleaded guilty to murder" [emphasis in original]. ${ }^{66}$ Without further explanation of the unstated mysteries known to "anyone who has ever watched television," the Court held that Rideau was deprived of due process by the trial court's failure to grant a change of venue to a community in which the interview had not been shown. The unstated assumption, to which the court hesitated to commit itself expressly, was that jurors who knew of - or, at least, had seen-the confession could not be impartial.

62. State v. Rideau, 242 La. 431,137 So. $2 d 283$ (1962).

63. 373 U.S. at 726.

64. Id. at 732 (Clark, J., dissenting).

65. Id. at 727 .

66. Id. at 726 . 
The approach followed by the court in the Rideau case was fundamentally different from that which had been employed by Chief Justice Marshall in Burr. Marshall had examined the statements and opinions of particular potential jurors to determine the nature and extent of their knowledge and its likely effect on their ability to be impartial. Stewart instead examined the publicity and made assumptions about its likely effect on the community generally. The unstated assumption behind the conclusion that a change of venue should have been granted-the assumption that knowledge of the confession would impair a juror's impartiality-is contrary to our law's long-standing recognition that there is no lack of harmony between knowledge and fairness.

The soundness of that long-standing view is suggested by the proposition that it would be a peculiar sort of legal system that asked Rideau's trial jury to ignore the fact that Rideau had repeatedly confessed to the crimes for which he was being tried.

Those confessions were made in circumstances that did not offend the then-prevailing constitutional doctrine of police interrogation. Although Justice Stewart's opinion refers to the fact that no lawyer was present when Rideau confessed "to advise him of his right to stand mute," ${ }^{67}$ the Court did not suggest that the absence of a lawyer in any way diminished the evidentiary force of the admissions Rideau undeniably made. In fact, the contents of those confessions, albeit not the film, were admitted into evidence at Rideau's trial.

The principles of Sheppard v. Maxwell and Rideau $v$. Louisiana seemed tailormade for the defendants in the Watergate cover-up case. If extrajudicial knowledge tainted a juror's ability to be impartial, then it was necessary to come to grips with the fact that the events of Watergate were probably the most extensively "reported" scandal in history. Moreover, Washington had the distinction, dubious or otherwise, of being the only place among a sample of U.S. locations (Delaware, Indianapolis, Richmond and Washington) where newspapers were the most important influence on public opinion. ${ }^{68}$

Moreover, if the function of the court was, as taught in Rideau, to analyze the quality and likely effect of the "publicity," then the court faced the extraordinarily delicate task of analyzing a mass of written and televised material that Haldeman's counsel colorfully, but not inaccurately, characterized as leading each prospective juror "to believe that his security and way of life was personally threatened by what [the defendants] had done," and that the jurors "were patriots repelling an attack on their country by an enemy within the gates." 69

67. Id. at 727 .

68. 559 F.2d at 143-44, 179 (MacKinnon, J., concurring and dissenting).

69. Id. at 62 n.37. 
In short, the principles articulated in the Sheppard and Rideau cases seemed to require, first, that a jury be composed of people who took no interest in one of the most widely discussed political controversies in history; and second, that federal courts analyze the quality and likely effect of television coverage and commentary of that political issue on a fair-minded juror.

Confronting the free press versus fair trial problem in the context of a political controversy, rather than the traditional crime of violence, presents the issues more clearly. The extreme nature of the results required by the application of the twin rulings of Rideau and Sheppard to the facts of Watergate suggests the desirability of a return to the traditional principles from which those cases departed. Under traditional principles, a juror's acquaintance with the facts of the case is no cause for alarm, and the focus of judicial inquiry is on the relative openmindedness of the juror, not the quality of the publicity.

In the Watergate case, the Court of Appeals teetered dangerously in the direction of judicial review of the fairness of Watergate reporting and commentary when it observed that: "The overwhelming bulk of the [publicity complained of by the appellants] consists of straightforward, unemotional factual accounts of events and of the progress of official and unofficial investigations."70 This judgment may or may not have been sound. Whatever its soundness, the prospect of judicial determinations of the fairness of political comment as an ingredient of criminal trials is a dubious one.

The Court of Appeals was on much sounder ground, then, when it withdrew from detailed analysis of the publicity, and held, instead, that an appellant seeking to demonstrate that "the jury was not sufficiently 'indifferent'" can do so "only by reference to the [voir dire]," 71 i.e., the method, employed by Marshall at the Burr trial, of evaluating the responses of individual veniremen to particular questions. Although the court went on to note, citing Rideau, that in "extreme circumstances" prejudice to the rights of the defendant might be presumed, it made clear that such circumstances were extreme indeed, and that in the case before it, the question of the impartiality of the jury was to be determined by a review of what the potential jurors said during voir dire examination-and not on an analysis of the quality of the publicity. ${ }^{72}$

In essence, the court was holding that, despite the enormous publicity surrounding the case and the admitted familiarity of the actual jury with some of that publicity, it could not be assumed that the jury would be anything but impartial. The decision in the Watergate case thus reflects a rejection of the assumption that knowledge is necessarily inconsistent with fairness.

It is fitting that our confidence in the ability of the informed jury to be

70. Id. at 61 (footnotes omitted).

71. Id. at 60 .

72. Id. at 60-63. 
fair should be vindicated in the context of Watergate. It is one of the tricks of history that we can never know when we might need an inscrutable "voice of the countryside" that speaks independently of the central government. It is worth remembering, in this context, that the government's prosecutor submitted the Watergate break-in case to the jury as nothing more than a third rate break-in.

The grand jury, that still-potent cognate of the petit or trial jury, retains the power to act on its own knowledge. ${ }^{73}$ The Watergate Grand Jury wished to indict President Nixon with the other defendants in the case. It was dissuaded from doing so by Special Prosecutor Jaworski. ${ }^{74}$

This decision could be second-guessed in the wake of the self-serving and self-profiting wave of publicity courted by that most famous of unindicted coconspirators, but there is no need or purpose to second guess either of the prosecutorial decisions above. It is enough to retain a skepticism for any argument against full participation by an informed citizenry in the system of justice.

73. Hale v. Henkel, 20I U.S. 43, 65-66 (1906).

74. L. Jaworski, The Right and the Power 100-01(1976). 